\title{
Refuge
}

Canada's Journal on Refugees

revue canadienne sur les réfugiés

\section{Tracing the Coloniality of Queer and Trans Migrations: Resituating Heterocisnormative Violence in the Global South and Encounters with Migrant Visa Ineligibility to Canada}

\section{Edward Ou Jin Lee}

Volume 34, numéro 1, 2018

Intersectional Feminist Interventions in the "Refugee Crisis"

URI : https://id.erudit.org/iderudit/1050855ar

DOI : https://doi.org/10.7202/1050855ar

Aller au sommaire du numéro

Éditeur(s)

Centre for Refugee Studies, York University

ISSN

0229-5113 (imprimé)

1920-7336 (numérique)

Découvrir la revue

Citer cet article

Lee, E. (2018). Tracing the Coloniality of Queer and Trans Migrations:

Resituating Heterocisnormative Violence in the Global South and Encounters with Migrant Visa Ineligibility to Canada. Refuge, 34(1).

https://doi.org/10.7202/1050855ar
Résumé de l'article

La plupart des travaux de recherche sur les migrants queer et trans ciblent leurs expériences postmigratoires. Cet article fait en revanche suite à une étude doctorale qui com-prend des entretiens avec les participants et une analyse de textes au contenu politique ou médiatique pour rendre les dimensions historiques, géopolitiques, sociales et écono-miques qui façonnent dans le monde non seulement la vio-lence homophobe et transphobe, mais aussi les migrations de personnes queers et trans des pays du Sud vers le Canada. Ces réalités sont analysées sous le prisme de la colonialité et à l'échelle de l'empire, afin d'historiciser la manière dont les vies des migrants queer et trans sont façonnées par des histoires oubliées de violence coloniale. Cette étude laisse penser que l’hypervisibilité du traitement " généreux » du Canada vis-à-vis des réfugiés queer et trans occulte la manière dont le régime frontalier empêche les personnes provenant des pays du Sud d'entrer dans ce pays.
Copyright (c) Refuge: Canada’s Journal on Refugees, 2018

Creative Commons Attribution NonCommercial 4.0 International License
Ce document est protégé par la loi sur le droit d'auteur. L'utilisation des services d’Érudit (y compris la reproduction) est assujettie à sa politique d'utilisation que vous pouvez consulter en ligne. 


\title{
Tracing the Coloniality of Queer and Trans Migrations: Resituating Heterocisnormative Violence in the Global South and Encounters with Migrant Visa Ineligibility to Canada
}

\author{
EDWARD OU JIN LEE
}

\begin{abstract}
Most of the scholarship on queer and trans migrants focuses on the refugee experience post-migration to Canada. In contrast, this article draws from a doctoral study that included participant interviews and policy/media textual analysis to map out the historical, geopolitical, social, and economic dimensions that shape homophobic and transphobic violence across the globe, as well as queer and trans migrations from the Global South to Canada. These realities are analyzed through the lens of coloniality and on the scale of empire to historicize how queer and trans migrant lives are shaped by forgotten histories of colonial violence. This study suggests that the hyper-visibility of Canada's "generous" treatment of queer and trans refugees obscures how its border regime blocks people from the Global South from entry.
\end{abstract}

\section{Résumé}

La plupart des travaux de recherche sur les migrants queer et trans ciblent leurs expériences postmigratoires. Cet article fait en revanche suite à une étude doctorale qui comprend des entretiens avec les participants et une analyse de textes au contenu politique ou médiatique pour rendre

(c) Edward Ou Jin Lee, 2018. This open-access work is licensed under a Creative Commons Attribution-NonCommercial 4.o International Licence, which permits use, reproduction, and distribution in any medium for non-commercial purposes, provided the original authorship is credited and the original publication in Refuge: Canada's Journal on Refugees is cited. les dimensions historiques, géopolitiques, sociales et économiques qui façonnent dans le monde non seulement la violence homophobe et transphobe, mais aussi les migrations de personnes queers et trans des pays du Sud vers le Canada. Ces réalités sont analysées sous le prisme de la colonialité et à l'échelle de l'empire, afin d'historiciser la manière dont les vies des migrants queer et trans sont façonnées par des histoires oubliées de violence coloniale. Cette étude laisse penser que l'hypervisibilité du traitement "généreux» du Canada vis-à-vis des réfugiés queer et trans occulte la manière dont le régime frontalier empêche les personnes provenant des pays du Sud d'entrer dans ce pays.

\section{Introduction}

anada has recently asserted itself as a global LGBTI
human rights leader, especially in its welcoming of
LGBTQ refugees. ${ }^{1}$ Indeed, some of the scholarship
and media accounts of LGBTI rights hail Canada as a "safe
haven" for LGBTQ refugees, while highlighting the pre-
migration experiences of homophobia and/or transphobia
(in countries of origin) as the primary, and sometimes only,
driver for why LGBTI people from the Global South flee to
Canada. ${ }^{2}$ However, a growing body of scholarship critiques

Cette œuvre en libre accès fait l'objet d'une licence Creative Commons Attribution-NonCommercial 4.0 International License, laquelle autorise l'utilisation, la reproduction et la distribution de l’euvre sur tout support à des fins non commerciales, pourvu que lauteur ou les auteurs originaux soient mentionnés et que la publication originale dans Refuge: revue canadienne sur les réfugiés soit citée. 
the Canadian refugee apparatus and highlights the structural and intersectional barriers faced by queer and trans ${ }^{3}$ migrants within and outside of the refugee determination system. ${ }^{4}$ These scholars also interrogate the ways in which homonational and settler colonial discourses and practices interweave through immigration and refugee processes. 5

However, most of the Canadian scholarship focuses on an analysis of the LGBTQ refugee experience after migration to Canada, and especially the refugee determination system. As a result, few scholars provide an in-depth portrait of the historical, geopolitical, social, and economic conditions that shape the realities of queer and trans people living in the Global South prior to their arrival. This article thus aims to map out these complex dimensions that shape contemporary forms of homophobic and transphobic violence across the globe, as well as queer and trans migrations from the Global South to Canada.

In order to do so, I draw from my doctoral study in which I conducted participant interviews and analyzed policy and media texts in order to trace how the realities of queer and trans migrants were socially organized by the Canadian immigration/colonization regime. ${ }^{6}$ Paying attention to social organization, as Roxana $\mathrm{Ng}$ suggests, allows for links to be made from "local experiences to broader social and global processes, which are not always immediately apparent at the local level."7 Although my study includes post-migration experiences, I have chosen to focus this article on my study participants' pre-migration experiences and contexts. More specifically, I examine the realities of queer and trans people living in the Global South by resituating their experiences of homophobia and transphobia in their countries of origin and then tracing their attempts to migrate to white/Western nation-states, including Canada.

The term white/Western, as conceptualized by Gada Mahrouse, ${ }^{8}$ highlights the complex relationship between race (whiteness), nation (Canadian), and geopolitical centre (Western). White signifies Canada's historical formation as a white settler society and its contemporary implications, while Western signifies its place of global power alongside the European Union and the United States. This framework binds the Canadian immigration/colonization regime to global power relations, which are often dictated by Western actors. This article explores how participants from my study were refused entry into multiple white/Western nationstates on the basis of visa eligibility requirements. These "encounters with ineligibility" reveal the ways in which white/ Western border regimes block entry of queer and trans people from the Global South and put into question the degree to which countries, such as Canada, can truly be "generous" towards migrants in general and LGBTQ refugees in particular. As part of a constellation of border regimes, "Canada's colonial project goes beyond its geo-political borders as a nation ... how different non-white bodies are placed within and/or arrive at the borders of the contemporary Canadian nation-state is a complex story of placemaking or the denial thereof, of arrival and becoming or of constantly being made to exist out-of-place."9

These processes of racialization and colonization are simultaneously gendered, classed, able-ized, ${ }^{10}$ and sexualized, resulting in an uneven and hierarchical distribution of life chances and exposure to death. ${ }^{11}$ I also draw from queer and trans diasporic critique to highlight how complex notions of home and nation are imbued by cisnormativity and heteronormativity. ${ }^{12}$ An analysis of cisnormativity reveals the ways in which social institutions and practices presume that everyone is "cis" - whereby one's gender identity and physical sex are entirely aligned, thus erasing trans realities and rigidly enforcing the gender binary. ${ }^{13}$ Whereas heteronormativity can be defined as the presumption that everyone is heterosexual through dominant institutions and practices that reproduce heterosexuality and naturalize monogamous marriage between a cis man and cis woman. ${ }^{14}$ I also use the term heterocisnormativity to highlight when cisnormativity and heteronormativity overlap.

Since the participants from my study span across Asia, Africa, and Latin America, I use an analytic that not only attends to geographically situated specificities, but also power relations on a global scale. Thus, coloniality, as coined by Anibal Quijano, provides a framework to map out a global matrix of power. ${ }^{15}$ The coloniality of power is obscured by the prevailing narratives of modernity: progress, civilization, development, and market democracy ${ }^{16}$ Modernity's form of global governance-the nation-state-emerged from the ashes of the many colonial projects driven by Europe, its desires for empire-building and, as Sylvia Wynter argues, "its construction of the 'world civilization' on the one hand, and, on the other, African enslavement, Latin American conquest, and Asian subjugation." 17 As such, the "residual intimacies" of conquest, slavery, and indentured labour persist and deepen into the present. ${ }^{18}$

A central feature of coloniality is how modernity has defined the "civilized" human subject as white people/whiteness in relation to the non-human black people/blackness. ${ }^{19}$ Anti-black logics that underpin white/Western empires persist in classifying people on a hierarchical scale of humanness, since, as Rinaldo Walcott suggests, "the Black body is not the most abject body in a competition of abjection and oppression, but the Black body is a template of how the abjection by which the Human was produced." ${ }^{\circ}$ Moreover, an analytical focus at the scale of empire makes legible what Jodi Byrd describes as the "cacophonies of colonialism"-interlacing colonial and imperial logics across geographies. ${ }^{21}$ 
This article seeks to historicize contemporary queer and trans migrations from the Global South to Canada to take into account the "fractured continuities" of "geographies and histories of empire, global capitalism, slavery, coerced labour, forced transportation, and exile [that] have materially shaped queerness, migration and queer migration, both past and present, including through the effects of haunting." ${ }^{22}$ This historicization situates contemporary forms of queer and trans migrations within histories of white/Western empire building to map out hierarchies within and across groups and locations while also contending with human classifications that were informed by colonial and imperial logics.

\section{Forgetting Colonial Histories of Cisnormative and Heteronormative Violence}

In this section I consider how the forgetting of colonial histories of social violence imbued by heterocisnormative processes indelibly shapes how queer and trans migrations from the Global South to Canada and other white/Western nation-states are articulated. Which acts of social violence are remembered and erased intimately shapes what and how we know what we know about contemporary forms of social violence and forced migrations. According to Lisa Lowe, there has been a lack of knowledge produced about the ties between "the slave trade and the extermination of native peoples that founded the conditions of possibility for indentureship; that stretches forward into the ubiquitous migrations of contemporary global capitalism." ${ }^{23}$

This forgetting of colonial and imperial violence and can be traced back to the nineteenth-century emergence of the Western European liberal philosophy of modern humanism. ${ }^{24}$ The liberal philosophy of modern humanism espoused a universal vision for economic freedom, political independence, and personhood through state citizenship, wage labour, the exchange market, and participation in a civil and secular society. However, a global racialized division of labour reveal that "colonial labor relations on the plantations in the Americas were the conditions of possibility for European philosophy to think the universality of human freedom, however much freedom for colonized peoples was precisely foreclosed within that philosophy." 25 This liberal philosophy that affirmed "universal" property rights and personhood was invested in white settlement in the colonies, land appropriation from Indigenous people in the Americas, slave trade of black Africans, and indentured Asian migrant labour, as well as the genocide of Indigenous peoples across Asia, Africa, and the Americas. ${ }^{26}$

Moreover, to achieve conquest over Africa, Asia, and the Americas between the nineteenth and twenty-first centuries, ${ }^{27}$ colonial powers were consumed by concern over what was called "carnal knowledge" in the colonies. ${ }^{28}$ Not only about sexual acts, "carnal knowledge" signified broader colonial desires to reorganize sexual relations in the colonies, since "the colonial management of sexuality, affect, marriage and family among the colonized formed a central part of the microphysics of colonial rule." 29 The colonial regulation of sexual relations included the realms of bodily contact and tactile relations (sexual or otherwise), along with sites for education, morality, health (hygiene), and family, ${ }^{30}$ socially reorganizing colonized societies through laws related to concubinage, marriage, and prostitution. ${ }^{31}$ These "intimacies of empire" were crucial to consolidate colonial power, as the "management of those domains provides a strong pulse on how relations of empire are exercised, and that affairs of the intimate are strategic for empire-driven states." 32

The intimacies of empire organized sexual relations not only in the colonies but also in the metropoles. ${ }^{33}$ The circulation of colonial discourses and practices related to sexuality and gender in the colonies were intimately tied to the emerging bourgeois class and intimacies in the metropole. 34 The desire for respectable bourgeois intimacies ${ }^{35}$ within the British Empire, for example, was reproduced through heterocisnormative processes tied to the nuclear family. ${ }^{36}$ The normative power of respectable middle-class domesticity was reinforced by eugenic discourses that "scientifically" labelled certain bodies as degenerate.

Applying "scientific knowledge," medical professionals classified phenotypical differences between white and racialized bodies, to mark racialized bodies as inferior. ${ }^{37}$ This marking of racialized bodies was simultaneously gendered, as racial difference was located differently between racialized cis men versus cis women. ${ }^{8}$ Along with producing racialized and gendered hierarchies, the classification scheme included a rigid two-sex system - male and female-with any variation deemed outside "normal" human biology. 39 Also samegender sexuality transitioned from being labelled as perverse sexual acts (sodomy) into a pathological condition inherent in individuals-homosexuality. ${ }^{\circ}$ These eugenic discourses were racialized, gendered, sexualized, able-ized, and classed, both marking deviancy and highlighting the boundaries of what was considered "normal" and "respectable." These eugenic discourses were also informed by imperial and colonial exploits, as "an intricate dialectic emerged-between the domestication of the colonies and the racializing of the metropolis." 41

This intricate dialectic between the colonies and the metropolis was reinforced through discourses of degeneracy, which considered sodomy/buggery as perverse acts and the eunuch/hermaphrodite as deviant, circulating globally through the imperial and colonial ventures of white/ Western men in Asia, Africa, and the Americas. ${ }^{42}$ Colonial rulers identified same-gender sexual activity and gender 
transgressions as deviant, thereby justifying its surveillance, policing, and criminalization. ${ }^{43}$ The heterocisnormative intimacies of empire reproduced an intricate dialectic that regulated and transformed sexual and gender relations between white bourgeois subjects and colonized peoples on a global scale. Thus the regulation of heterocispatriarchy through the creation of white respectability versus racialized degeneracy was integral to colonial and imperial exploits not only globally, but also in the making of a white settler society in Canada. The erasure of these heterocisnormative processes as central to colonial and imperial exploits and imbricated into the principles of white supremacy and patriarchy intimately shape contemporary discourses on queer and trans migrations. These discourses often reproduce a liberationist narrative 44 in which queer and trans people migrate from the "backward" and "uncivilized" Global South to total freedom in "modern" and "civilized" white/Western nationstates, such as Canada.

\section{Political, Material, and Transnational Dimensions of Homophobic and Transphobic Violence}

In this section I unpack the historical, political, and transnational dimensions that shape the homophobic and transphobic violence experienced by two participants from my study. My study included thirteen queer and trans migrants from the Global South, ranging from Central and North Africa, to Southeast and Western Asia, Central America, Mexico, and the Caribbean. The interviews were conducted after participants had migrated to Canada, from 2009 to 2014. Everyone interviewed described experiences of homophobia and/or transphobia prior to migrating to Canada. These acts of oppression were perpetrated by family and community members as well as state agents. Interpersonal and statesanctioned homophobic and/or transphobic violence were an integral part of everyday life. However, the intensity and scope of homophobic and transphobic violence differed between individuals and across regions, countries, communities, and families. Participants often described how they were abandoned and sometimes persecuted by family and friends while also experiencing police surveillance, torture, and imprisonment for transgressing gender norms and/or getting "caught" in engaging in same-gender sexual activity.

The following section provides an in-depth examination of the experiences of Jean Michel and Lana. I pay particular attention to the geographic and political specificities of Jean Michel's and Lana's experiences of interpersonal and statebased heterocisnormative violence. Although both individuals are from different regions of Africa (Cameroon) and the Caribbean (Jamaica), the ways in which heterocisnormative violence operates in their lives signal geopolitical complexities and forgotten histories of colonial violence.

\section{Jean Michel, Cameroon, and French Colonial Legacies}

From Cameroon, Jean Michel is a young gay man who is primarily French speaking, interested in sports, and university educated. A major event in his life in Cameroon was when he was incarcerated for being identified as a homosexual. At a certain point, Jean Michel's imprisonment was in the media, increasing his public recognition as a gay person. "I was persecuted in my city ... after having left prison, all of my family abandoned me. I was persecuted by my friends, my family, my community, by everyone. I was at risk to being returned to prison for homosexuality, if I remained in my country." 45

This heteronormative violence was shaped by a broader historical and political context. The legal text that sanctioned Jean Michel's imprisonment was article 347 of the Cameroon penal code, which states that anyone who engages in "sexual relations" with someone of the same sex will face imprisonment from six months to five years, along with a fine of between 20,000 to 200,000 francs. ${ }^{46}$ The criminalization of same-gender sexual relations can be traced back to anti-sodomy laws imposed by French colonial rule in early $20^{\text {th }}$ century Cameroon as part of a broader colonial juridical apparatus meant to ensure control over indigenous populations. ${ }^{47}$ The latest iteration of criminal laws against same-sex sexuality was established in 1972, a little over a decade after Cameroon had gained independence from French colonial rule. ${ }^{48}$

Although the international media situated the context of the imprisonment and persecution of individuals such as Jean Michel in Cameroon as yet another example of a "homophobic Africa," Patrick Awondo suggests unpacking the political and material conditions of homophobia in Cameroon. ${ }^{49}$ During a period of mass unemployment experienced by the majority of the Cameroon population, privately owned media outlets, along with religious and student leaders identified homosexuality as a Western and colonial import that had infiltrated the corrupt political elite. ${ }^{50}$ Some media outlets recycled the criticism that the outgoing colonial administration, at the precise birth of an independent Cameroon post-colonial nation-state in 1960, had instrumentalized "homosexuality" as a pathway for political advancement of the handpicked elite, making "colonial homosexuality" a "symbol of the fawning compromise between the current political elite ... and France, the former colonial power." 51

Some newer media outlets, competing against their more well-established counterparts, were the first to post the names and photos of some of the political elite who were thought to be homosexual. This accusation was buttressed by religious leaders (mostly Catholic) and student groups, and led to a charged political environment in which the government responded by targeting of mostly poor/working-class men who were imprisoned for engaging in same-sex sexual acts 
and whose names and photos were first posted in a couple of privately owned media outlets and then elsewhere..$^{52}$ The instrumentalization of homosexuality, as Western depravity practised by some political leaders, served to reassert moral and political power for student and religious leaders in the face of state suppression. 53

However, Awondo insists that another set of actors within media, legal, and health spheres also contests this framing of "colonial homosexuality" within the political elite as a primary cause of mass poverty. Some media outlets questioned the journalistic integrity of the newer newspapers who had published material that were deemed violations of privacy. 54 Also obscured is an emerging, yet complicated LGBTI human rights movement in Cameroon. One organization garnered the political and financial support of most white/Western NGOs for their focus on sexual health and leadership of educated men who identify as gay/homosexual, in contrast with another organization that engaged with a "universal human rights" approach that did not directly confront state powers but focused more on respecting individual privacy. 55 Jean Michel himself spoke of key individuals in Cameroon who had assisted him when he was being incarcerated and in his migration trajectory to Canada.

\section{Lana, Jamaica, and English Colonial Legacies}

Lana identifies as gay and male, but uses "she" pronouns. Although she does not use the term trans, her reflections about her sexual and gender identity reveal the ways in which she lives in the world as a gender non-conforming person. Since childhood, Lana experienced daily experiences of hetero-cisnormative violence for being gender non-conforming: "All my life, my community, persons, they identify me before I even knew who I was, that I was gay. I knew I was something different. But I didn't know what it was called ... and in the process of searching for me, I was identified by my community in a very derogatory way, as in being bashed all the time, calling 'faggot,' 'battyman,' 'gay' ... as a young child, I was terrified, I was petrified."

Lana also had allies, key friends, or family members who helped her to stay safe or flee. "My two sisters ... they knew that I'm gay and they were supportive, so they tried to hide my stuff and keep most of my stuff. But I have to be in isolation with my friend [name] from December until I leave the island in April. It was very hard ... it was bondage. It's not easy when you have to hide under the covers at night, in a car."

Although Lana did not experience incarceration based on her sexual orientation and/or gender identity, she does refer to being homosexual in Jamaica as illegal. The legal text making same-gender sexual relations illegal can be traced back to the imposition of the 1864 Offences against the Person Act by the British colonial government, which prohibited "acts of gross indecency" (sexual acts) between men, and "buggery" (sodomy) in general. ${ }^{56}$

As Jamaica became its own nation-state in 1962, the Indigenous elite preserved a large range of pre-existing laws, including making "gross indecency" and "buggery" criminal to prove their competency in post-colonial governance. 57 Similar to other post-colonial Caribbean nation-building projects, a heterosexual and patriarchal social order was reinforced by the governing elite in Jamaica through promoting a moral code that identified non-procreative sex, such as gay or lesbian sex, as foreign to the nation's cultural norms..$^{58}$ As these laws from the colonial era expanded to include same-gender sexual relations between women, white/ Western-driven structural adjustment programs refashioned definitions of masculinity and femininity through the privatization of women's labour (i.e., funding cuts to health, social services, and education).

At the same time, Blake and Dayle suggest that some queer and trans people in Jamaica have actively resisted this particular framing and criminalization of same-gender sexual relations for over five decades. The formation of gay and lesbian identity in Jamaica emerged in the 1970s, taking up "gay liberation" discourses that had emerged out of the United States in the 1960s.59 Blake and Dayle describe three time periods, or waves, of sexual minority-based activisms, which included consciousness-raising activities, pushing for constitutional protection, and decriminalization. During the latest wave of activism by local activists, international law and human rights convention frameworks have been mobilized, to place international reputational and economic pressure on the Jamaican government. However, there has also been a shift in transnational activism related to LGBTI human rights, with tensions arising between the objectives and strategies of white/Western actors within the international human rights movement and local Jamaican LGBTQ activists. ${ }^{60}$

This tension surfaced in my interview with Lana, who referenced the effects of a threatened Jamaican tourism boycott that was initiated by a Canadian-based coalition that demanded that the Jamaican government address its violation of LGBTQ rights. "I remember when there was a boycott from Canada from the gay community here, and trust me, that reaped up a storm in Jamaica, because people were going around and attacking gay people more than ever. We were being attacked more than ever because of what was published in the paper and on the radio station there, and they're like 'these things can't happen here' ... so people were attacking. I can remember that."

Although Lana doesn't explicitly reference who from the "gay community" in Canada initiated the boycott, the period in which Lana referenced this experience was precisely when a public campaign was launched by the coalition Stop 
Murder Music Canada (sMmc). ${ }^{61}$ The coalition called upon leaders of the Canadian music industry to stop selling and broadcasting homophobic dancehall artists. ${ }^{62}$ In addition to applying public pressure to key actors within the Canadian music industry, the sMMc lobbied the federal minister of immigration to refuse entry to anti-gay reggae artists on the grounds that some of their lyrics violated Canadian criminal and human rights laws. ${ }^{63}$ In 2008 the sMMC launched a public campaign that threatened to call for a Jamaican tourism boycott if the Jamaican government did not denounce homophobic violence, repeal the criminalization of homosexuality, include sexual orientation into the Jamaican Charter of Rights, and develop educational campaigns. ${ }^{64}$ The call for a Jamaican tourism boycott sparked debate. ${ }^{65}$

Lana refers to the time "when there was a boycott from Canada from the gay community" and then how the boycott "reaped up a storm in Jamaica." However, upon receiving an official response from the Jamaican government, the SMMC ultimately decided not to proceed with the tourism boycott. ${ }^{66}$ Lana articulates the impact of a proposed tourism boycott, rather than a fully realized one. Lana links this proposed tourism boycott to an increase in attacks on her and other LGBTI Jamaicans "because of what was published in the paper and on the radio station." Lana's reflections gesture to the transnational trajectory of public text-mediated discourses initiated by the SMMC coalition in Canada. The call for a boycott of Jamaican tourism by the SMMC coalition was then mediated by Canadian news media, in particular LGBTQ media, which were, in turn, rearticulated by Jamaican news media.

A more thorough investigation into the social organization of the SMMC coalition call for boycott and its impact on the everyday lives of LGBTI Jamaicans is outside the scope of this study. However, the linkages described by Lana connect the SMMC coalition's boycott call with an increase in attacks against LGBTI Jamaicans and reveals the power of certain public text-mediated discourses. In this case, the material effects occurred from activities and texts initiated by the SMMC coalition, which were then dispersed into a transnational public sphere through media outlets in Canada and Jamaica. These public text-mediated discourses, rearticulated by Canadian and Jamaican news media, then circulated through Canadian and Jamaican politico-administrative regimes and private enterprises (i.e., music companies), as can be evidenced by the cancellation of concert venues and removal of songs from iTunes, and the direct response to the sMmC coalition by the Jamaican government.

The strategies and impact of the SMMC coalition's call for a boycott echoes an earlier, similar campaign run by Outrage! in the United Kingdom in 2003. In their criticism of the Stop Murder Music (sMM) campaign by Outrage!, Blake and Dayle suggest that exclusion of local Jamaican LGBTI activists from this initiative resulted in a "resurgence of ethno-nationalistic sentiment and a hardening of views on homosexuality following the campaign. Many felt that SMM bore the disquieting undertones of a civilizing mission-a bid to reform the barbarous bloodthirsty culture." 67 The SMMC coalition in Canada thus reproduced these dynamics, resulting in an increase in violence against LGBTI individuals like Lana.

\section{Intergenerational Colonial Legacies}

The criminalization of sexual and gender transgression in both Jean Michel's and Lana's regions-Cameroon and Jamaica-can be traced back to nineteenth- and twentiethcentury British and French empire building. ${ }^{68}$ Colonial laws that criminalized sexual and gender transgressions (i.e., sodomy, "eunuchs," vagrancy, etc.) operated as a key tool of white/Western empire building to contain and control the colonized. As one tool of many, these laws should be situated within the broader colonial management of racialized, gendered, and sexualized relations. Although colonial rulers claimed their aim was humanitarian, to improve the lives of the colonized, "in practice, however, imperialist interventions in sexuality could also enforce local patriarchies, stigmatize alternative sexualities, and serve as instruments of imperial control over colonized peoples." 69 The policing, surveillance, and erasure of Indigenous sexualities and genders, as interpreted by colonial powers, served as key mechanisms through which many Indigenous societies were reorganized..$^{70}$ The boundaries of heterocisnormative intimacies demarcated which sexualized and gendered behaviours and colonized bodies would be consigned to life or death. This consolidated the colonial relation of the civilized (heterosexual/cissexual) white/Western subject versus the uncivilized perverse Other.

The factors that compel queer and trans people from the Global South to migrate thus cannot be contained to "acts of homophobia/transphobia," since "African homophobia does not exist, nor does European homophobia, Asian homophobia or South American homophobia ... we must understand homophobic acts within their specific local histories as these intersect with broader global histories." ${ }^{11}$ Such historicization renders visible histories of colonial violence and challenges the current framing of the global LGBTI human rights agenda.

Indeed, all participants in my study referred to their parents and/or grandparents, most of whom lived in Asia or Africa during the period of anti-colonial struggle that forced British and French colonial rulers to withdraw, after establishing "post-colonial" nation-states. ${ }^{72}$ This was also the precise period when previous anti-sodomy and vagrancy laws once imposed on an "immoral" colonized people were reconfigured into a political tool for the emerging political 
elite to identify these colonial laws as integral to the cultural values of the newly established nation-state. ${ }^{73}$ Some scholars suggest that this key shift was partly an anti-colonial reaction against colonial rulers who framed sexual and gender transgressions as inferior cultural practices of the perverse colonial subjects. 74

With this shift, the extended history of the colonial management of sexual relations was erased, along with the colonial violence required to impose the heterocisnormative intimacies of empire. On the basis of one interview, it is difficult to trace the intergenerational effects of this period on the present-day lives of participants. However, this intergenerational history exists and informed how their parents transmitted notions of sexuality and gender.

It is thus the colonial making of these nation-states with mostly white/Western-backed authoritarian regimes that not only reinforced the patriarchal heterosexual/cissexual citizen 75 but also shaped subsequent mass refugee movements, as the displacements from anti-colonial struggles during the 1960 s were also caused by the global proliferation of capitalism and imperialism. ${ }^{76}$ There were also neocolonial continuities in the ways in which mostly white/ Western economic interests continued to guide the political decisions of emerging militarized dictatorships across the Global South. ${ }^{77}$ Nearly all of the participants were born in the 1980s and 1990s, during the era of imposed structural adjustment programs by the International Monetary Fund and World Bank. ${ }^{78}$ These economic measures were imposed by mostly white/Western-backed authoritarian regimes and entrenched pre-existing global economic inequalities, resulting in the devaluation of local currency, decline in the level of social services, and greater privatization of women's unpaid labour.79

These white/Western-driven capitalist processes of recolonization included the making of loyal heterosexual/ cissexual citizens, in relation to perverse Others. ${ }^{80}$ Central to the post-independence nation-building project was the maintenance of a heterosexual, cissexual, and patriarchal social order, through discourses of "family values," the promotion of heterosexual monogamous marriage, and continued criminalization of sexual and gender transgressions. ${ }^{81}$ The prevailing social order was also accomplished partly through the policing of cis women's sexualities and genders, as the criminalization of sexual and gender transgressions expanded to include same-gender sexual activity between two women. ${ }^{82}$ The emerging global neo-liberal economic order was thus reinforced through the policing of women's sexualities and strengthened criminalization of sexual and gender transgressions.

This global economic context becomes the "structural base" for the everyday violence against queer and trans people "as a political weapon in the hands of disenfranchised groups that are themselves victims of the structural violence in an unequal economic system." 83 The Rwandan genocide that Sammy fled was shaped not only by the colonial legacy of inter-ethnic hierarchies established by Belgian colonizers prior to their departure, but also economic collapse, as "the macro-economic reforms imposed by international creditors ... played a crucial role in fostering the collapse of state institutions and creating a situation of social and political divisiveness." 84 Sammy explains that the motivation to flee Rwanda was shaped by his economic status (as poor) and fear of homophobic violence interlinked with the emerging genocide. Ultimately, each participant from my study was differently situated within global colonial legacies, which shaped their present-day realities. It is these complex and multi-layered realities that compelled them to migrate to white/Western nation-states.

\section{Encounters with Visa Ineligibility}

In this section I examine the ways in which queer and trans people from the Global South encounter visa eligibility requirements to gain entry into white/Western nation-states. I have explored how queer and trans migrants obtained temporary visa/permits to enter Canada. ${ }^{85}$ However, my aim here is to highlight the circumstances under which participants were not able to obtain visas/permits. More specifically, I examine the text-based processes that organized the migration attempts to Europe and Canada of four study participants: Sammy (Rwanda), Sarah (Algeria), Sayad (Azerbijan) and Lana (Jamaica).

When Sayad and his partner's circumstances, as a gay couple, rapidly shifted in response to the homophobic threats they faced from his partner's parents, they began to desperately search for a way to leave Azerbaijan. Although Sayad had already previously lived in the United States as an international student, this past migration experience did not help him find a way to leave Azerbaijan. Sayad's encounter with ineligibility was tied to visitor visa requirements:

We were considering ... [going] to Norway and claim refugee status there ... it wasn't working out at all ... I tried international organization for migration, I tried UNHCR, I tried various other organizations that are stationed both in our home country and overseas and I didn't receive any response or any kind of assistance ... the only way for us to ... apply for refugee status in Norway is to actually be physically in Norway. So you can't do it outside of Norway ... we couldn't get a visa to Norway unless we have an invitation from someone ... they don't provide tourist visas without invitation.

In Sayad's case, entry into Norway required an invitation from someone from Norway. Similarly, Sarah, as a trans 
woman living in Algeria, describes attempting to contact multiple LGBT organizations in Europe and Canada, only to be told that they could help her only if she were able to first enter the country.

There was an association, one person who worked in an association ... [in] Spain. So he told me, "ok look, this is what we will do. I will send you an invitation. As if you are invited to participate in a conference here in Spain for people," they told me, for LGBT [people] ... so I received the invitation, everything was good ... you know that Algeria with Western countries, to be able to get a visa, it was really difficult. You can't get a visa. It's really closed ... so I submitted my [visa] request. They told me that I have to wait twenty days or one month. So, I received a negative decision. ${ }^{86}$

For both Sarah and Sayad, the "letter of invitation" emerged as a central text related to the eligibility requirements to migrate to a European country. Becoming eligible for a visitor visa not only depended on their own ability to fulfill eligibility criteria (i.e., income level), but acceptance also hinged upon the recommendation of a white/Western citizen or organization. Even with the invitation letter from a conference organizer in Spain, Sarah received a negative decision on her visitor visa application, resulting in her trying to obtain a visa elsewhere. For Sammy, the desire to migrate to Europe and/or Canada/United States was not an encounter with ineligibility, but rather, a long-term relationship with ineligibility. As a teenager, Sammy wanted to migrate to Europe as an international student, recognizing its value (i.e., increased employment opportunities when returning to Rwanda): "It was very difficult to be able to register for any university. It was difficult to be able to pay for these studies. It was difficult to locate funding ... from international organizations that could cover the costs for these studies ... it was really complicated to receive a bursary from these organizations. And it was very difficult for the Rwandan government be able to, at the very least, pay for these studies." ${ }^{87}$

For both Sammy and Sarah, the financial requirements proved to be a significant hurdle to obtaining a visitor visa and/or study permit. Sammy describes how being from southern Rwanda made it more difficult to receive government financial support to study abroad, as northern Rwandans were favoured by the government, at that time. Sammy's long-term relationship to ineligibility was thus organized by his location within Rwandan politics.

These participants' navigation through Canadian and European visa/permit application processes reveal the transnational character of queer and trans migrant encounters with ineligibility. Indeed, most participants in my study made multiple attempts to access a temporary visa/permit to enter a white/Western nation-state and were sometimes unsuccessful. These attempts reveal the ways in which eligibility criteria such as income requirements, invitation letters, and bi-national scholarship arrangements are fundamental to blocking migrants from the Global South to enter white/ Western nation-states.

At the same time, these participants actively negotiated visa/permit application procedures that, on the surface, appear to be rigid. Many of the participants' previous experiences of migrant exclusion shaped their decision to obtain a Canadian visa/permit. Sarah's and Sayad's encounters with ineligibility reveal how the $\mathrm{EU}^{88}$ visa/permit application process was unresponsive to the heterocisnormative violence that shaped their attempt to obtain a visa/permit in the first place. Key eligibility criteria thus organized a dividing line between ineligibility versus eligibility, regardless of one's sexual and/or gender identity.

\section{"Encounters with Ineligibility" versus Canada as a "Safe Haven" for LGBTQ Refugees}

My study suggests that queer and trans people from the Global South are often deemed ineligible for a visa/permit to enter white/Western nation-states, including Canada. These encounters with ineligibility reveal the ways in which visa/ permit eligibility operates as a tool of migrant exclusion that is ultimately disinterested in the realities of queer and trans people from the Global South. This transnational tool of exclusion targets poor/working-class queer and trans people in the Global South especially, marking them as almost always ineligible. Prior to the start of WorldPride 2014 in Toronto, a number of Ugandan "gay rights advocates" were refused entry for lack of travel history and family ties in Canada, and insufficient funds for the trip. ${ }^{89}$ In 2017 a Tunisian LGBTQ activist who was invited to present in Canada described how his visitor visa application (and those of other LGBTQ people he knew) was refused, at least partly for fear that they would seek refugee status upon entry to Canada. 90 These visa refusals of LGBTQ people also occur within the context of visa refusals for a disproportionate number of any person from the Global South. Prior to the 2016 World Social Forum in Montreal, over 200 people, mostly from the Global South, had their visitor visa application denied. ${ }^{91}$

Some scholars have examined how queer and trans migrants, especially refugees, come to embody and navigate homonationalist discourse. ${ }^{92}$ In contrast, this article sheds light on some of the consequences of this discourse. The stories of "exceptional" LGBTQ refugees who are "saved" by Canada circulate through media and policy texts, obscuring the realities of thousands of people from the Global South, including some who are queer and trans, who are refused entry. The erasures of these stories make it easier for Canada 
and other white/Western nation-states to articulate themselves as global leaders of LGBTI human rights and a "safe haven" for LGBTQ refugees. This is especially the case with Canada, which has made hyper-visible the recent improvements to the refugee claim process to be more "queer and trans friendly," such as the implementation of guidelines for refugee claims based on sexual orientation and gender identity and expression (sogIE). ${ }^{93}$ This hyper-visibility obscures a global border regime driven by white/Western nation-states, including Canada, that actively blocks queer and trans people from the Global South from accessing the refugee claim process through visa ineligibility.

To be clear, my assertion here is not a critique of the advocacy that led to improvements in the refugee claim process. These guidelines will most certainly assist a certain number of LGBTQ refugee claimants and help to ensure that the refugee adjudication process will not be based on stereotypes. ${ }^{94}$ However, this analysis does elicit critical questions about the political usefulness of publicly lauding a "queer and trans friendly" refugee claim process when the queer and trans people who need it the most can't access it.

The "encounters with ineligibility" that study participants experienced also reveal a deepening alignment of Canadian and European borders. The exclusion from Europe of some participants was shaped by interstate migration policies of the EU which include a border-control regime aimed explicitly to block "irregular" migration to Europe. ${ }^{95}$ Those who attempt to enter EU member states without a valid visa/permit are considered "irregular migrants," even if they are identified as in need of international protection. ${ }^{96}$ More recently the EU has facilitated labour mobility and trade between EU member states while simultaneously closing the borders to most potential migrants from the Global South. ${ }^{97}$ The mobility for some and racialized exclusion of others has been described by some as "Fortress Europe," as belonging to the Eu results in mobility and economic privileges for Europeans while "the continent's external borders are increasingly fortified ... non-Europeans may break the law-and accordingly might be treated as criminals-simply by being present." ${ }^{\prime 8}$

In September 2014 Canada signed the Comprehensive Economic and Trade Agreement with the EU, described as the more "ambitious" and "broader in scope" than the North American Free Trade Agreement, opening new markets to the benefit of Canadians. A couple of weeks later, Citizenship and Immigration Canada announced the inclusion of additional European countries to the Designated Country of Origin list and included a statement by the minister of citizenship and immigration, Chris Alexander, stating, "Thanks to our government's reforms to Canada's asylum system, we are providing protection quickly to those who are truly in need while protecting our system from abuse. We will continue to welcome legitimate trade and travel with our European partners. ${ }^{99}$ This quote directly links recent reforms to refugee policy with the Canada-Eu free trade agreement and affirms the neo-liberal shift in Canadian governance that correlates refugees with security, sovereignty, and border control. ${ }^{100}$

Moreover, the regulation of visas/permits is organized by designated CIC visa offices located in Canadian embassies as well as visa application centres (VACs), meant to assist individuals in submitting and tracking applications for visitor visas, work permits, and study permits. ${ }^{101}$ The United Kingdom and Swiss-based company that operates Canadian vaCs is vFs Global, a subsidiary of the Kuoni Group and is "the world's largest outsourcing and technology services specialist for governments and diplomatic missions worldwide."102 Making explicit how temporary visas are organized and often coordinated across white/Western border regimes (and motivated by corporate economic interests) reveals the subtle yet deep-rooted manner in which the coloniality of power operates on a global scale.

In addition, the local realities and forced migration trajectories of Lana (Jamaica), Sammy (Rwanda), and Jean Michel (Cameroon) reveal the ways in which anti-blackness underpins white/Western empires and border regimes. Tracing their collective histories reveals how black people and Africans have endured slavery and a "cacaphony of colonialisms"103 from European powers (Britain, France, Belgium). Prior to landing in Canada, these participants migrated (or attempted to) multiple times, across Europe and Africa. Sammy was refused entry onto a plane, many times, in an attempt to eventually enter Canada. "An individual sold me his passport because he had travelled to the US and he had a multiple entry visa ... I tried multiple times to take the plane ... they would trap me. I was almost taken to jail, but fortunately, there were people who helped me to find a Zimbabwe passport, through government connections."104

These multiple migration trajectories reveal how antiblack logics result in black people being constantly "out of place." At yet Lana, Jean Michel, and Sammy responded to white Western border regimes in acts of refusal, and, as Jack Halberstam argues, "It is a game-changing kind of refusal in that it signals that refusal of the choices as offered."105 Although outside the scope of this article, it is crucial to note that queer and trans migrants employ multiple strategies of survival and resistance in order to navigate and at times fight back against the colonial and imperial logics that organize policies and institutions aimed at their exclusion or removal.

\section{Conclusion}

In 2015 a new Liberal government took power in Canadian Parliament, led by the charismatic Prime Minister Justin Trudeau. Since this time, a member of Parliament has been 
named the special advisor on LGBTQ2 issues, and in 2017 Canada publicly announced its role as co-chair (with Chile) of the Equal Rights Coalition, an intergovernmental network comprising over thirty countries focused on "promoting" and "protecting" LGBTI human rights globally. ${ }^{106}$ These changes have resulted in a significant shift in policy vis-à-vis migrants, as highlighted by the resettlement of over 45,000 refugees. Certainly this is a stark contrast to the recent election of Donald Trump as the president of the United States.

However, the visa/permit application procedures remain in place, as demonstrated by the visa refusals for the World Social Forum in 2016 and the gay Tunisian activist in 2017. At the same time, the Comprehensive Economic and Trade Agreement between Canada and the United States officially came into effect. Although these recent geopolitical shifts merit further attention, the continued imbrication between Canadian and European border regimes suggests a further fortressing of white/Western nation-states that seem interested in queer and trans people from the Global South only when they enter refugee claim process that is difficult to access.

My study findings suggest a rearticulation of the intimacies of white/Western empires ${ }^{107}$ and the links between heterocisnormative violence in the Global South with national, regional, and transnational contexts of civil war, genocide, dictatorship, revolution, development, resource extraction, and generalized violence. Global and domestic neo-liberal economic policies have operated in concert with the growth of religious fundamentalisms, resulting in an increase in state violence, including the expansion of criminal laws against sexual and gender transgressions. ${ }^{108}$ The political, social, and transnational conditions for queer and trans people in the Global South are intimately linked to the ways in which either they are blocked from white/Western nation-states or they enter as migrants with precarious status.

Tracing back the lives of queer and trans migrants living in Canada to their countries of origin and their intergenerational histories fundamentally shifts what and how we know what we know about contemporary forms of social violence and forced migrations. This process of historicization gestures to the ways in which the "residual intimacies" of conquest, slavery, and indentured labour continue to "haunt" queer and trans migrants from the Global South who are presently living in Canada. The question becomes how scholars and activists challenge dominant liberationist discourses of queer and trans migrations and delve into "an ethics and politics in struggling to comprehend the particular absence of the intimacies of four continents, to engage slavery, genocide, indenture and liberalism, as a conjunction, as an actively acknowledged loss within the present."109

The violent forgetting of these complex histories of colonial violence has greatly contributed to the notion that queer and trans migrations to Canada are a result of simple "acts of homophobic and transphobic violence" by barbaric and uncivilized cultures. ${ }^{110}$ This affirms the importance for queer and trans migration scholars to engage in broader analyses of coloniality, anti-blackness, and border regimes of white/ Western nation-states. However, shifting the focus on postmigration realities of queer and trans migrants in Canada requires engaging with an analytical frame that contends with the ways in which white settler colonial logics inform queer and trans migrations.

Finally, by situating heterocisnormative violence in the Global South and subsequent queer/trans migrations within complex histories of global capitalism and empire, scholars challenge liberationist narratives ${ }^{111}$ and instead gesture to queer and trans decolonial and abolitionist futures. A queer and trans decoloniality, as Paola Bacchetta suggests, deploys "strategies and tactics for resisting not just one or another relation of power at a time, but rather the ensemble of coconstitutive relations of power in question, inseparably ... it is to draw near to opening a space, and holding space, for the creative construction for other ways of life."112

\section{Notes}

1 David A. B. Murray, Real Queer? Sexual Orientation and Gender Identity Refugees in the Canadian Refugee Apparatus (London: Rowman \& Littlefield, 2016); Edward Ou Jin Lee, Trish Hafford-Letchfield, Annie Pullen Sansfaçon, Olivia Kamgain, and Helen Gleeson, The State of Knowledge about LGBTQI Migrants Living in Canada in Relation to the Global LGBTQI Rights Agenda (Montreal: Université de Montréal, 2017).

2 Ainsley Jenicek, Edward Lee, and Alan Wong, "Dangerous Shortcuts': Representations of LGBT Refugees in the Post 9/11 Canadian Press," in "Race and Ethnicity," special issue, Canadian Journal of Communications 34, no. 4 (2009): 63558; Olivier Roy, "The Colour of Gayness: Representations of Queers of Colour in Québec's Gay Media," Sexualities (2012): 175-90; Murray, Real Queer?

3 In this paragraph, I have transitioned between terms such as LGBTI, LGBTQ, and queer and trans. As identity categories, the terms queer and trans are limited in fully capturing complex lived realities. My use of these terms extends beyond identity categories to also engage with queer and trans theories and politics. See Lionel Cantu, The Sexuality of Migration: Border Crossings and Mexican Immigrant Men (New York: NYU Press, 2009).

4 Murray, Real Queer?; Sharalyn Jordan, "Un/Convention(al) Refugees: Contextualizing the Accounts of Refugees Facing Homophobic or Transphobic Persecution," Refuge 26, no. 2 (2010): 165-82; Edward Ou Jin Lee and Shari Brotman, "Identity, Refugeeness, Belonging: Experiences of Sexual Minority Refugees in Canada," Canadian Review of Sociology 48, no. 3 (2011): 241-74. 
5 Murray, Real Queer?; Katherine Fobear, "Queer Settlers: Questioning Settler Colonialism in LGBT Asylum Processes in Canada," Refuge 30, no. 1 (2013): 47-56; Melissa White, "Ambivalent Homonationalisms: Transnational Queer Intimacies and Territorialized Belongings," Interventions 15, no. 1 (2013): 37-54.

6 I use the term immigration/colonization regime in order to highlight the ways in which immigration and colonization to Canada are both informed by the historical desire for white settlement and the ongoing logics of white settler colonialism.

7 Roxana Ng, "Exploring the Globalized Regime of Ruling from the Standpoint of Immigrant Workers," in Sociology for Changing the World: Social Movements / Social Research, ed. Caelie Frampton, Gary Kinsman, A. K. Thompson, and Kate Tilleczek (Halifax: Fernwood Publishing, 2006), 186.

8 Gada Mahrouse, Conflicted Commitments: Race, Privilege, and Power in Transnational Solidarity Activism (Montreal and Kingston: McGill-Queen's University Press, 2014).

9 Rinaldo Walcott, "The Problem of the Human: Black Ontologies and 'the Coloniality of Our Being," in Postcoloniality-Decoloniality_Black Critique, ed. Sabine Broeck and Carsten Junker (New York: Campus Verlag, 2013), 99.

10 The term able-ized suggests that the classification of mental and physical disabilities were socially constructed and employed to justify the oppression of people with disabilities (i.e., feeble-minded, dumb, stupid, etc.).

11 Sherene Razack, Malinda Smith, and Sunera Thobani, eds., States of Race: Critical Race Feminism for the 21st Century (Toronto: Between the Lines, 2010).

12 Jasbir Puar, "Transnational Sexualities: South Asian (Trans) nation(alism)s and Queer Diaspors," in Asian American Sexualities: Dimensions of the Gay and Lesbian Experience, ed. R. Leong, 405-22 (New York: Routledge, 1996); David L. Eng, "'Out Here and over There': Queerness and Diaspora in Asian American Studies," Social Text 52/53 (1997): 31-52; Jin Haritaworn, "Colorful Bodies in the Multikulti Metropolis: Vitality, Victimology and Transgressive Citizenship in Berlin," in Transgender Migrations: The Bodies, Borders and Politics of Transition, ed. T. T. Cotton, 11-31 (New York: Routledge, 2012); Nael Bhanji, "Trans/scriptions: Homing Desires, (Trans)sexual Citizenship and Racialized Bodies," in Cotton, Transgender Migrations, 157-75.

13 Julia Serano, Whipping Girl: A Transsexual Woman on Sexism and the Scapegoating of Femininity (Emeryville, CA: Seal, 2007); Greta R. Bauer, Rebecca Hammond, Robb Travers, Mathias Kaay, Karin M. Hohendel, and Michelle Boyce, "I don't think this is theoretical-This is our lives': How Erasure Impacts Health Care for Transgender People," Journal of the Association of Nurses in AIDS Care 20, no. 5 (2009): 348-61.

14 Cathy Cohen, "Punks, Bulldaggers and Welfare Queens: The Radical Potential of Queer Politics?" Feminist Theory 4, no. 3 (1997): 359-64.

15 Anibal Quijano, "Coloniality of Power and Eurocentrism in Latin America," International Sociology 14, no. 2 (2000):
215-32; Walter D. Mignolo, "Further Thoughts on (De)coloniality," in Broeck and Junker, Postcoloniality-Decoloniality-Black Critique, 21-52; Sandeep Bakshi, Suhraiya Jivraj, and Silvia Posocco, Decolonizing Sexualities: Transnational Perspectives Critical Interventions (Oxford: Counterpress, 2016).

16 Mignolo, "Further Thoughts on (De)coloniality," 26.

17 Sylvia Wynter, "Unsettling the Coloniality of Being/Power/ Truth/Freedom: Towards the Human, after Man, Its Overrepresentation-An Argument," CR: Centennial Review 3, no. 3 (2003): 257-337.

18 Lisa Lowe, The Intimacies of Four Continents (Durham, NC: Duke University Press, 2016), 19.

19 Walcott, "Problem of the Human"; Wynter, "Unsettling the Coloniality ofBeing." For morescholarship on anti-blackness and colonialism, see also Tiffany King, "Labor's Aphasia: Towards Antiblackness as Constitutive to Settler Colonialism," Decolonization: Indigeneity, Education \& Society (2014): https://decolonization.wordpress.com/2014/06/10/ labors-aphasia-toward-antiblackness-as-constitutive-tosettler-colonialism/; Jared Sexton, "The Vel of Slavery: Tracking the Figure of the Unsovereign," Critical Sociology 42, nos. 4-5 (2014): 1-15; Délice Mugabo, "On Rocks and Hard Places: A Reflection on Antiblackness in Organizing against Islamophobia," Critical Ethnic Studies 2, no. 2 (2016): 159-83.

20 Walcott, "Problem of the Human," 100.

21 Jodi Byrd, The Transit of Empire: Indigenous Critiques of Colonialism (Minneapolis: University of Minnesota Press, 2011).

22 Eithne Luibheid, "Queer/Migration: An Unruly Body of Scholarship," GLQ 14, no. 2-3 (2008): 169-9o; Eithne Luibheid and Lionel Cantu, Queer Migrations: Sexuality, us Citizenship and Border Crossings (Minnesota: University of Minnesota Press, 2005).

23 Lisa Lowe, "The Intimacies of Four Continents," in Haunted by Empire: Geographies of Intimacy in North American Intimacy, ed. Laura Ann Stoler (Durham, NC: Duke University Press, 2006), 206.

24 Lowe, The Intimacies of Four Continents; Charles W. Mills, "Racial Liberalism," PMLA 123, no. 5 (2008): 1380-97.

25 Lowe, The Intimacies of Four Continents, 193.

26 Lowe, The Intimacies of Four Continents; Mills, Racial Liberalism.

27 Ania Loomba, Colonialism/Postcolonialism (New York: Routledge, 2005); Edward Said, Orientalism (London: Vintage, 1979).

28 Ann Laura Stoler, Carnal Knowledge and Imperial Power: Race and the Intimate in Colonial Rule (London: University of California Press, 2002).

29 Lowe, The Intimacies of Four Continents, 193.

30 Lisa Carty, "The Discourse of Empire and the Social Construction of Gender," in Scratching the Surface: Canadian Anti-Racist Feminist Thought, ed. Enaki Dua and Angela Robertson, 35-47 (Toronto: Women's Press, 1999); Ann McClintock, Imperial Leather: Race, Gender and Sexuality 
in the Colonial Context (New York: Routledge, 1995). See Stoler, Carnal Knowledge.

31 Ann Laura Stoler, "Making Empire Respectable: The Politics of Race and Sexual Morality in 2oth-Century Colonial Cultures," American Ethnologist 16, no. 4 (1989): 636-60. See Stoler, Carnal Knowledge.

32 Ann Laura Stoler, "Intimidations of Empire: Predicaments of the Tactile and Unseen," in Haunted by Empire: Geographies of Intimacy in North American Intimacy, ed. Ann Laura Stoler, 1-22 (Durham, NC: Duke University Press, 2006); Mytheli Sreenivas, "Sexuality and Modern Imperialism," in A Global History of Sexuality: The Modern Era, ed. Robert M. Buffington, Eithne Luibheid, and Donna J. Guy, 57-88 (Oxford: Wiley Blackwell, 2014).

33 See Stoler, "Intimidations of Empire."

34 See Carty, "Discourse of Empire"; Gary Kinsman, "Constructing Sexual Problems: These Things May Lead to the Tragedy of Our Species," in Power and Resistance: Critical Thinking about Canadian Social Issues, ed. Wayne Antony and Les Samuelson, 256-82 (Halifax: Fernwood Publishing, 1998); see Loomba, Colonialism/Postcolonialism.

35 Lowe, The Intimacies of Four Continents.

36 Leonore Davidoff, Worlds Between: Historical Perspectives on Gender and Class (Cambridge: Polity, 1995); Mary Louise Fellows and Sherene Razack, "The Race to Innocence: Confronting Hierarchical Relations among Women," Gender, Race and Justice 1 (1998): 335-52. See Kinsman, "Constructing Sexual Problems."

37 McClintock, Imperial Leather; S. B. Somerville, Queering the Color Line: Race and the Invention of Homosexuality in American Culture (Durham, NC: Duke University Press, 2000).

38 Somerville, Queering the Color Line.

39 Anne Fausto-Sterling, Sexing the Body: Gender Politics and the Construction of Sexuality (New York: Basic Books, 2000).

40 John D'Emilio, Sexual Politics, Sexual Communities: The Making of the Homosexual Minority in the United States, 1940-1970 (Chicago: University of Chicago Press, 1983); Gary Kinsman, The Regulation of Desire: Homo and Hetero Sexualities (Montreal: Black Rose Books, 1996).

41 D’Emilio, Sexual Politics, Sexual Communities, 43.

42 Robert Aldrich, Colonialism and Sexuality (New York: Routledge, 2003); Rudi C. Bleys, The Geography of Perversion: Male to Male Sexual Behavior outside the West and the Ethnographic Imagination, 1750-1918 (New York: New York University Press, 1995); Martin Cannon, "The Regulation of First Nations Sexuality," Canadian Journal of Native Studies 1, no. 1 (1998): 1-18; Alok Gupta, This Alien Legacy: The Origins of "Sodomy" Laws in British Colonialism (New York: Human Rights Watch, 2008); Joey L. Mogul, Andrea J. Ritchie, and Kay Whitlock, Queer (In)Justice: The Criminalization of LGBT People in the United States (Boston: Beacon, 2011); Richard C. Trexler, Sex and Conquest: Gender Violence, Political Order and the European Conquest of the Americas (Ithaca: Cornell University Press, 1999).
43 As Alok Gupta suggests, "The colonized needed compulsory re-education in sexual mores ... 'native' viciousness and 'white' virtue had to be segregated; the latter praised and protected, the former policed and kept subjected" (Gupta, Alien Legacy, 5). See also Aldrich, Colonialism and Sexuality; see Bleys, Geography of Perversion; Mogul, Ritchie, and Whitlock, Queer (In)Justice; Chris Finley, "Decolonizing the Queer Native Body (and Recovering the Native Bull-Dyke): Bringing 'Sexy Back' and out of the Native Studies Closet," in Queer Indigenous Studies: Critical Interventions in Theory, Politics and Literature, ed. Qwo-Li Driskill, Chris Finley, Brian Joseph Gilley, and Scott Lauria Morgensen, 31-42 (Tucson: University of Arizona Press, 2011); S. Gannon, "Exclusion as Language and the Language of Exclusion: Tracing Regimes of Gender through Linguistic Representations of the "Eunuch," Journal of the History of Sexuality 20, no. 1 (2011): 1-28.

44 Luibheid, "Queer/Migration."

45 This quote was translated. Here is the original quote: J'étais persécutée dans ma ville... après être sortie de la prison, toute ma famille mabandonner. J'étais persécuté par des amis, par l'entourage, le voisinage, par tout le monde. J'avais des risques dêtre remis dans prison pour l'homosexualité si je restais dans mon pays.

46 Lucas Paoli Itaborahy and Jingshu Zhu, State-Sponsored Homophobia. A World Survey of Laws: Criminalisation, Protection and Recognition of Same-Sex Love (Geneva: ILGA, 2014).

47 Gupta, Alien Legacy.

48 Patrick Awondo, "The Politicisation of Sexuality and Rise of Homosexual Movements in Post-Colonial Cameroon," Review of African Political Economy 37, no. 125 (2010): 31528; Patrick Awondo, Peter Geschiere, and Graeme Reid, "Homophobic Africa? Toward a More Nuanced View," African Studies Review 55, no. 3 (2012): 145-68.

49 Awondo, "Politicisation of Sexuality."

50 Awondo, "Politicisation of Sexuality."

51 Awondo, "Politicisation of Sexuality," 317.

52 Awondo, "Politicisation of Sexuality."

53 Awondo, "Politicisation of Sexuality."

54 Awondo, "Politicisation of Sexuality."

55 Awondo, "Politicisation of Sexuality", 323.

56 Conway Blake and Phillip Dayle, Beyond Cross-Cultural Sensitivities: International Human Rights Advocacy and Sexuality in Jamaica (London: Institute of Commonwealth Studies, School of Advanced Study, University of London, 2013).

57 Blake and Dayle, Beyond Cross-Cultural Sensitivities.

58 M. Jacqui Alexander, "Pedagogies of Crossing: Meditations on Feminism, Sexual Politics, Memory and the Sacred". Duke University Press, 2005; Blake and Dayle, Beyond Cross-Cultural Sensitivities.

59 Blake and Dayle, Beyond Cross-Cultural Sensitivities; D’Emilio, Sexual Politics, Sexual Communities.

6o Blake and Dayle, Beyond Cross-Cultural Sensitivities. 
61 The sMmC was a working group of the Canadian Caribbean Human Rights Groups and included organizations such as Egale Canada, the Metropolitan Community Church of Toronto, and the African Canadian Social Development Council.

62 Akim Ade Larcher and Colin Robinson, "Fighting 'Murder Music': Activist Reflections," Caribbean Review of Gender Studies: A Journal of Caribbean Perspectives on Gender and Feminism 3 (2009): 1-12; Amar Wahab, "Calling 'Homophobia' into Place (Jamaica) Homo/trans/nationalism in the Stop Murder Music (Canada) Campaign" Interventions 18, no. 6 (2016): 908-28.

63 Krishna Rau, "Koolhaus Cancels Concerts amid Queer Outrage," Xtra, October 10, 2007; Rau, "More Dancehall Acts Cancelled over Homophobic Lyrics Controversy," Xtra, November 21, 2007; Rau, "iTunes Canada Pulls Anti-Gay Dancehall Songs," Xtra, April 6, 2008, http://dailyxtra.com/ canada/arts-and-entertainment/itunes-canada-pulls-antigay-dancehall-songs. The SMMC also cancelled concert venues and arranged with iTunes to remove tracks from some Jamaican reggae artists who included homophobic lyrics in some of their songs. These tactics by the SMMC were inspired by the Stop Murder Music campaign run a few years earlier by Peter Tatchell from the UK organization OutRage! On its website, Outrage! describes itself as "a broad based group of queers committed to radical, non-violent direct action and civil disobedience" (http://outrage.org .uk/about/). A central feature of their work is the combat of homophobia at an international level, particularly in Africa.

64 KrishnaRau, "MurderMusicandBoycotts,"Xtra, May6,2008, https://www.dailyxtra.com/murder-music-and-boycotts15891; Rau, "Jamaica's Queer Group Says Boycott Bad Idea," Xtra, April 7, 2008; Rau, "Jamaica Boycott Call Sparks War of Words," Xtra, 24 April 2008, https://www.dailyxtra.com/ jamaica-boycott-call-sparks-war-of-words-38298; I. Ashtante, "Murder Music Sparks Caribbean Tourism Boycott Call," Star, March 3, 2008, https://www.thestar.com/news/ 2008/03/03/murder_music_sparks_caribbean_tourism_ boycott_call.html.

65 Rau, "Jamaica's Queer Groups Says Boycott Bad Idea."

66 Krishna Rau, “Jamaica Boycott Called Off,” Xtra, May 20, 2008, https://www.dailyxtra.com/jamaica-boycott-called-off-38214.

67 Blake and Dayle, Beyond Cross-Cultural Sensitivities, 468.

68 See Gupta, This Alien Legacy; see Bleys, Geography of Perversion; Stoler, "Making Empire Respectable."

69 Sreenivas, "Sexuality and Modern Imperialism," 76.

70 See Gupta, This Alien Legacy; Mogul, Ritchie, and Whitlock, Queer (In)Justice; see Qwo-Li Driskill, Chris Finley, Brian Joseph Gilley, and Scott Lauria Morgensen, eds., Queer Indigenous Studies: Critical Interventions in Theory, Politics, and Literature (Tucson: University of Arizona Press, 2011).

71 Keguro Macharia, "Homophobia Is Not a Single Story," Guardian, May 26, 2010: http://www.theguardian.com/commentisfree/2010/may/26/homophobia-africa-not-singlestory.
72 M. Jacqui Alexander and Chandra Talpade Mohanty, Feminist Genealogies, Colonial Legacies, Democratic Futures (New York: Routledge, 1997).

73 Alexander, "Pedagogies of Crossing"; Awondo, "Politicisation of Sexuality"; Awondo, Geschiere, and Reid, "Homophobic Africa?"; Bleys, Geography of Perversion; Blake and Dayle, Beyond Cross-Cultural Sensitivities; Gupta, This Alien Legacy; Hasan El Menyawi, "The Great Reversal: How Nations in the Muslim World Went from Tolerating Same-Sex Practices to Repressing LGB People, 1750-2010" (unpublished, 2012); Joseph A. Massad, Desiring Arabs (Chicago: University of Chicago Press, 2007); Hassan El Menyawi, "Activism from the Closet: Gay Rights Strategizing in Egypt," Melbourne Journal of International Law 7, no. 1 (2012): 28-40; Rinaldo Walcott, "Black Men in Frocks: Sexing Race in the Gay Ghetto (Toronto)," in Claiming Space, ed. C. Teelucksingh, 121-33 (Waterloo, on: Wilfrid Laurier University Press, 2006).

74 Bleys, Geography of Perversion; Walcott, "Black Men in Frocks."

75 Alexander, "Pedagogies of Crossing."

76 Bhupinder S. Chimni, "The Geopolitics of Refugee Studies: A View from the South," Journal of Refugee Studies 11, no. 4 (1998): 350-74; C. Skran, Refugees in Inter-War Europe (Oxford: Clarendon, 1995).

77 Alexander and Talpade Mohanty, Feminist Genealogies, Colonial Legacies, Democratic Futures; Sokari Ekine, "Contesting Narratives of Queer Africa," in Queer African Reader, ed. S. Ekine and H. Abbas. 78-91 (Dakar: Pambazuka, 2013).

78 Alexander and Talpade Mohanty, Feminist Genealogies, Colonial Legacies, Democratic Futures; Alexander, "Pedagogies of Crossing"; Awondo, "Politicisation of Sexuality"; Joel Beinin and Frédérick Vairel, Social Movements, Mobilization, and Contestation in the Middle East and North Africa (Stanford: Stanford University Press, 2013); Blake and Dayle, Beyond Cross-Cultural Sensitivities; Massad, Desiring Arabs; Menyawi, "Activism from the Closet"; El Menyawi, "Great Reversal"; Chandra Talpage Mohanty, Feminism without Borders: Decolonizing Theory, Practising Solidarity (Durham, NC: Duke University Press, 2004).

79 Alexander and Talpade Mohanty, Feminist Genealogies, Colonial Legacies, Democratic Futures; Daiva K. Stasiulis and Abigail B. Bakan, Negotiating Citizenship: Migrant Women in Canada and the Global System (Toronto: University of Toronto Press, 2005).

80 Alexander and Talpade Mohanty, Feminist Genealogies, Colonial Legacies, Democratic Futures.

81 Alexander, "Pedagogies of Crossing"; Ekine, "Contesting Narratives of Queer Africa."

82 Gupta, This Alien Legacy; Alexander, "Pedagogies of Crossing."

83 Lyn Ossome, "Postcolonial Discourses of Queer Activism and Class in Africa," in Queer African Reader, ed. Sokari Ekine and Hakima Abbas (Dakar: Pambazuka, 2013), 37. 
84 Michel Chossudovsky, "Economic Reforms and Social Unrest in Developing Countries," Economic and Political Weekly 19 (1997): 1788.

85 Edward Ou Jin Lee, "Responses to Structural Violence: The Everyday Ways in Which Queer and Trans Migrants with Precarious Status Respond to and Resist the Canadian Immigration Regime," International Journal of Child, Youth \& Family Studies, in press.

86 Translation: Il y avait une association, une personne qui travaillais dans une association ... Espagnole. Donc, il m'a dit “Oh, regard, qu'est-ce qu'on va faire. Je vais t'envoyer une invitation. Comme quoi tu es invité pour assister à une conférence ici en Espagne pour les personnes," ils mont pas dit LGBT ... donc j'ai reçu l'invitation, cétait correct et tout ... vous savez que l'Algérie avec les pays occidentales, c'est pour faire un visa, cétait vraiment difficile. Tu ne peux pas faire un visa. C'est vraiment enfermé ... donc j’ai fait ma demande. Ils mont dit il faut attendre vingt jours ou un mois. Donc, j’ai reçu la réponse négative.

87 Translation: Cétait très difficile de trouver une inscription dans les universités. C'était difficile de pouvoir payer ces études. C'était difficile de trouver des financements ... à partir (des) organismes internationaux qui peuvent payer les études ... cétait très compliqué d'avoir une bourse d'études dans ces organismes-là. Et cétait très difficile que le gouvernement Rwandais puisse payer, par exemple, au moins les études.

88 Applicants for inclusion within the Treaty on European Union must meet the "Copenhagen criteria" (as articulated in 1993), which include stable democratic institutions, promote human rights, have a functioning market economy, and adhere to a cohesive political, economic, and monetary union (https://europa.eu/european-union/sites/europaeu/ files/docs/body/treaty_on_european_union_en.pdf).

89 Nicholas Keung, "Uganda Gay Activists Denied Visas to World Pride Conference," Star, May 22, 2014, http://www .thestar.com/news/gta/2014/05/22/ugandan_gay_activists_ denied_visas_to_world_pride_conference.html.

90 Émilie Larivée-Tourangeau, "Ce n'est pas demain que les homosexuels étranger envahiront le Canada," vicE, August 4, 2017, https://www.vice.com/fr_ca/article/3kd3jy/ce-nestpas-demain-que-les-homosexuels-etrangers-envahirontle-canada.

91 Canadian Press, “Rejection of Delegates' Visas to Montreal Conference Hurts Canada's Reputation, Organizer Says," Star, August 8, 2016, https://www.thestar.com/news/canada/2016/o8/o8/rejection-of-delegates-visas-to-montrealconference-hurts-canadas-reputation-organizer-says.html.

92 Murray, Real Queer?; White, "Ambivalent Homonationalisms."

93 Nicholas Keung, "Refugee Board Creates Guidelines for Deciding LGBTQ Claims," Star, May 5, 2017, https://www. thestar.com/news/immigration/2017/05/05/refugeeboard-creates-guidelines-for-deciding-lgbtq-claims.html. Immigration and Refugee Board of Canada, "Chairperson's
Guideline 9: Proceedings before the IRB Involving Sexual Orientation and Gender Identity and Expression," 2017.

94 Lee and Brotman, "Identity, Refugeeness, Belonging"; Nicole La Violette, "Gender-Related Refugee Claims: Expanding the Scope of the Canadian Guidelines," International Journal of Refugee Law 19, no. 2 (2007): 1-47.

95 Amnesty International, The Human Cost of Fortress Europe: Human Rights Violations against Migrants and Refugees at Europe's Borders (London: UK Amnesty International, 2014); Fatima El-Tayeb, "The Birth of a European Public: Migration, Postnationality and Race in the Uniting of Europe," in Nation and Migration: Past and Future, ed. D. G. Gutiérrez and P. Hondagneu-Sotelo, 649-70 (Baltimore: Johns Hopkins University Press, 2009).

96 A major feature of the border control regime includes the surveillance and patrolling of major land and sea migration pathways from the Global South to Europe. Funded by the Solidarity and Management of Migration Flows Program, the EU assigned $€ 1.8$ billion, nearly 50 per cent of its budget (between 2007 to 2013), to EU border control initiatives in comparsion to €700 million, or 17 per cent of its budget, to refugee programs. Some border control practices include mass detention, deportation, and readmission agreements. Readmission agreements allow EU states to push irregular migrants back to their partner country. Some readmission agreements include Greece and Turkey, Spain and Morocco, and France and Benin. Amnesty International, Human Cost of Fortress Europe.

97 Stephen Castles, "Towards a Sociology of Forced Migration and Social Transformation," Sociology 37, no. 1 (2003): 13-34; S. Castles, H. De Hass, and M. J. Miller, The Age of Migration: International Population Movements in the Modern World, 5th ed. (New York: Guilford, 2014); El-Tayeb, "Birth of a European Public."

98 Canada already exchanges its fingerprint database with the United States, Australia, and the United Kingdom. Fingerprinting is required for all temporary residents who require a temporary visa/permit. A white/Western controlled biometric database to track migrants mostly from the Global South may soon exist. El-Tayeb, "Birth of a European Public," 149. A key feature of the Eu border control regime is the use of Eurodac, a fingerprint database that tracks irregular migrants and asylum seekers. Chris Jones, "Analysis: 11 Years of Eurodac," Statewatch, 2014, http://www.statewatch .org/analyses/no-235-eurodac.pdf; Wendy Chan and Dorothy Chunn, Racialization, Crime and Criminal Justice in Canada (Toronto: University of Toronto Press, 2014).

99 Citizenship and Immigration Canada, "Protecting Canada's Asylum System from Abuse," news release, October 10, 2014, para 6, https://www.canada.ca/en/news/archive/ 2014/10/protecting-canada-asylum-system-abuse.html.

100 Audrey Macklin, "Disappearing Refugee: Reflections on the Canada-US Safe Third Country Agreement," Columbia Human Rights Law Review 36 (2005): 365-426; S. J. Aiken, "Of Gods and Monsters: National Security and Canadian 
Refugee Policy," Revue Québécoise de droit international 14 (2001): 7-36.

101 Citizenship and Immigration Canada, "Immigration, Refugees and Citizenship Canada (IRCC) Offices," http://www.cic .gc.ca/english/information/offices/; Citizenship and Immigration Canada, "Find a Visa Application Centre," http://www .cic.gc.ca/english/information/offices/vac.asp.

102 Citizenship and Immigration Canada, "Find a Visa Application Centre."

103 Byrd, Transit of Empire.

104 Original quote: “À partir d’un (individu), il m’a vendait un passeport, parce que lui il avait voyage aux États-Unis et il avait un visa multiple entrées ... j’avais essayé plusieurs fois de prendre l'avion ... arriver à l'aéroport ... on m’a attrapais. J'ai failli entrer en prison, mais heureusement qu'il y a des gens qui m’avaient aidé à trouver ce passeport Zimbabwe, avais des connections dans le gouvernement."

105 Jack Halberstam, "The Wild Beyond: With and for the Undercommons," in The Undercommons: Fugitive Planning \& Black Study, ed. S. Harney and F. Moten (Brooklyn: Autonomedia, 2013), 8.

106 Global Affairs Canada, "Canada and Chile Co-Chair Equal Rights Coalition," news release, June 20, 2017, https://www .canada.ca/en/global-affairs/news/2017/06/canada_and_ chileco-chairequalrightscoalition.html.

107 Stoler, "Intimidations of Empire."

108 Ossome, "Postcolonial Discourses of Queer Activism and Class in Africa"; K. Kaoma, Colonizing African Values: How the U.S. Christian Right Is Transforming Sexual Politics in Africa (Somerville: Political Research Associates, 2013); S. Ndashe, "The Single Story of 'African Homophobia' Is Dangerous for LGBTI Activism," in Queer African Reader, ed. Sokari Ekine and Hakima Abbas, 155-64 (Dakar: Pambazuka, 2013).

109 Lowe, Intimacies of the Four Continents, 40.

110 Ainsley Jenicek, Edward Lee, and Alan Wong, "Dangerous Shortcuts': Media Representations of Sexual Minority Refugees in the Post 9/11 Canadian Press," Canadian Journal of Communications 34, no. 4 (2009): 635-58; Murray, Real Queer?

111 Lionel Cantu, The Sexuality of Migration: Border Crossings and Mexican Immigrant Men (New York: New York University Press, 2009); E. Luibheid, "Introduction: Queering Migration and Citizenship," in Queer Migrations: Sexuality, US Citizenship and Border Crossings, ed. E. Luibheid and L. Cantu, xi-xlvi (Minnesota: University of Minnesota, 2005).

112 Paola Bacchetta, “QTPOC Critiques of 'Post-Raciality', Segregationality, Coloniality and Capitalism in France," in Decolonizing Sexualities: Transnational Perspectives Critical Interventions, ed. S. Bakshi, S. Jivraj, and S. Posocco (Oxford: Counterpress, 2016), 278.

Edward Ou Jin Lee is an assistant professor at the Université de Montréal. The author may be contacted atwje.lee@umontreal.ca. 